\title{
Closure of patent ductus arteriosus with oversized Amplatzer occluder in a patient with pulmonary hypertension
}

Zamknięcie przetrwałego przewodu tętniczego za pomocą ponadwymiarowego okludera Amplatzer u chorego z nadciśnieniem płucnym

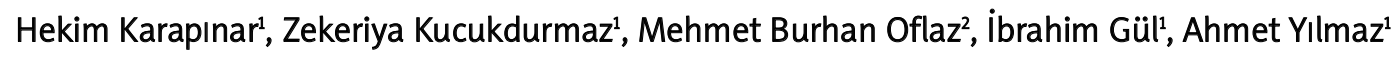 \\ 1Department of Cardiology, Cumhuriyet University Medical Faculty, Sivas, Turkey \\ 2Department of Pediatric Cardiology, Cumhuriyet University Medical Faculty, Sivas, Turkey
}

Postep Kardiol Inter 2013; 9, 1 (31): 93-96

DOI: $10.5114 /$ pwki.2013.34033

\begin{abstract}
Diagnosis of patent ductus arteriosus is rare in adulthood. Closure of ductus is difficult when diagnosed at an adult age due to the development of pulmonary hypertension and pulmonary arterial disease that generally occurs. Closure of the ductus might be contraindicated, as it may lead to deterioration of the pulmonary arterial perfusion or to a pulmonary hypertensive crisis. In addition, another risk associated with percutaneous closure for these patients is the risk of embolism of the asymmetrically shaped device to the systemic circulation. We present in this manuscript a case with patent ductus arteriosus diagnosed at an adult age that underwent successful closure by the percutaneous method. During closure, an oversized Amplatzer duct occluder device was used to reduce the risk of device embolism.
\end{abstract}

Key words: patent ductus arteriosus, percutaneous closure, catheterization.

\section{Streszczenie}

Przetrwały przewód tętniczy rzadko jest stwierdzany u osób dorosłych. Zamknięcie przewodu u tych pacjentów jest utrudnione ze względu na częste współwystępowanie nadciśnienia płucnego i choroby tętnic płucnych. W takich przypadkach zamknięcie przewodu może być przeciwwskazane, ponieważ może ono prowadzić do pogorszenia perfuzji tętnic płucnych lub do wystąpienia przełomu nadciśnienia płucnego. Dodatkowym czynnikiem ryzyka związanym z przezskórnym zamknięciem przewodu u tych osób jest ryzyko przemieszczenia się asymetrycznie usytuowanego urządzenia do krążenia systemowego (zatorowości). W pracy przedstawiono przypadek pacjenta z przetrwałym przewodem tętniczym rozpoznanym w wieku dorosłym i skutecznie leczonym metodą przezskórną. W celu zmniejszenia ryzyka przemieszczenia się urządzenia do zamknięcia ubytku wykorzystano ponadwymiarowy okluder Amplatzer.

Słowa kluczowe: przetrwały przewód tętniczy, zamknięcie przezskórne, cewnikowanie.

\section{Introduction}

Patent ductus arteriosus (PDA) is a congenital pathology generally diagnosed and closed during childhood. Large PDAs can cause left heart failure, left heart dilatation, pulmonary vascular disease, Eisenmenger syndrome and right heart failure. So, it is recommended that when large ductus is diagnosed, it should be closed either surgically or preferentially percutaneously [1]. If left open until adulthood, the closure of the ductus might be contraindicated as it may lead to the development of pulmonary vascular diseases, the deterioration of pulmonary arterial perfusion or to a pulmonary hypertensive crisis. For patients with very high pulmonary artery pressure, another risk of percutaneous PDA closure is of the protrusion and finally embolization of the asymmetric device to the aorta $[2,3]$.

\section{Aim}

In the case presented in this manuscript with a moderate-to-large ductus and pulmonary hypertension, the duct

\section{Corresponding author/Adres do korespondencji:}

Assist. Prof. Hekim Karapınar MD, Cumhuriyet University Medical Faculty, Cumhuriyet Üniversitesi Hastanesi Kardiyoloji Anabilim Dall, 58140 Sivas, Turkey, tel.: +905053149560, e-mail: drhekim@yahoo.com

Received: 7.08.2012, accepted: 8.11.2012. 
was occluded with an "oversized" Amplatzer duct occluder to prevent the risk of device embolization.

\section{Case report}

A 28-year-old male patient working as an agricultural worker was directed to our clinic by a physician who identified cardiac murmur during his physical examination. The patient had presented to this physician with complaints of shortness of breath and easy exhaustion. A continuous cardiac murmur was heard during the patient's examination, and transthoracic echocardiography (TTE) was performed. Enlarged left heart cavities (with a left ventricular diastolic diameter of $67 \mathrm{~mm}$ ) and ascending aorta (39 mm) were observed in the TTE. Trace to $1 / 4$ aortic insufficiency and trace to $1 / 4$ mitral insufficiency were identified. In the parasternal short axis view obtained using color Doppler, a continuous passage (10 $\mathrm{mm}$ in diameter) from the aorta to the pulmonary artery was observed. A patent ductus was identified that was $9 \mathrm{~mm}$ in diameter on the two-dimensional echocardiography. Also, a $44 \mathrm{~mm} \mathrm{Hg}$ systolic pressure gradient was measured across the ductus.

Diagnostic and interventional heart catheterization was planned for the patient, who was considered as a possibly suitable candidate for percutaneous closure. Sheaths of $6 \mathrm{Fr}$ and $8 \mathrm{Fr}$ were placed in the right femoral artery and the right femoral vein, respectively. Pressures of the left and right heart were measured. Aortic pressure was 115/65 (85) $\mathrm{mm} \mathrm{Hg}$ and pulmonary artery pressure (PAP) was 70/30 (45) $\mathrm{mm} \mathrm{Hg}$. Aortography was performed at $90^{\circ}$ in the left

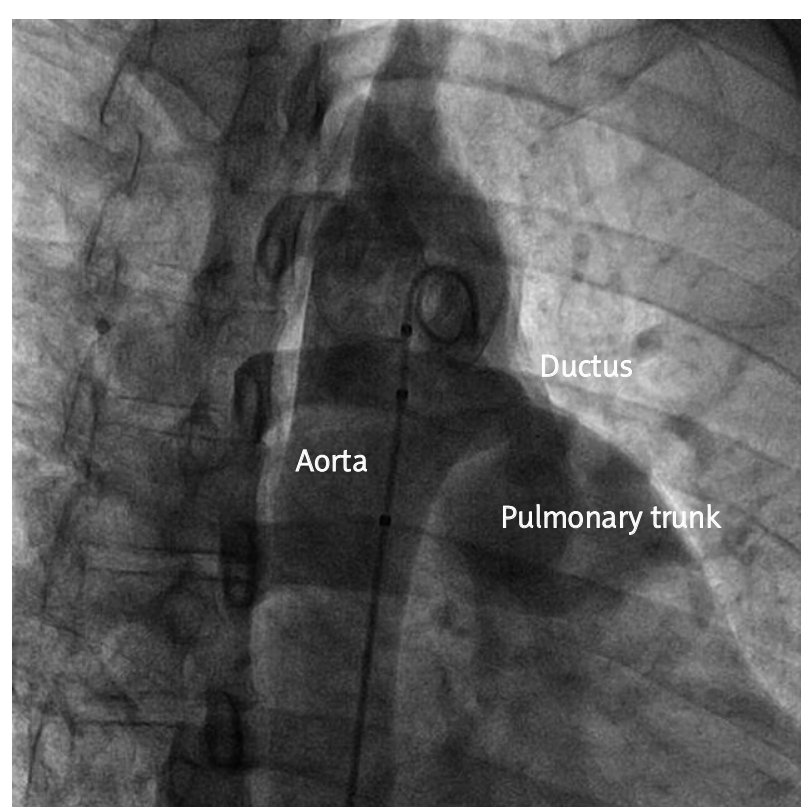

Fig. 1. Passage into the pulmonary artery through the wide ducts opening can be observed on the aortography

Ryc. 1. Przejście do tętnicy płucnej poprzez szerokie wejście do przewodu widoczne w aortografii lateral and $45^{\circ}$ in the right anterior oblique view with a marked pigtail catheter (Figure 1). The waist of the ductus was measured as $9 \mathrm{~mm}$ by aortography. A pulmonary-to-systemic flow ratio of 2.3 and a pulmonary vascular resistance of $2.8 \mathrm{WU}$ were calculated. Based on the recommendations of the manufacturer [4], the implantation of a 14-12 Amplatzer duct occluder device (ADO, AGA Medical Corp., Golden Valley, Minnesota) was considered. However, due to the asymmetric design of the ADO device, and as the patient had high PAP and an occupation that involved heavy duty, it was considered that the device might embolize to the aorta. Since the patient's ductus length (18 $\mathrm{mm})$ and aortic ampulla $(20 \mathrm{~mm})$ were both sufficient, it was decided that the one size larger 16-14 ADO device could be used. Intravenous heparin (80 IU/ $/ \mathrm{kg}$ ) and cefazolin $(1000 \mathrm{mg})$ injection was performed. The pulmonary artery was catheterized with the 6 Fr pigtail catheter. Despite repeated attempts, the catheter with the 0.038 inch guidewire could not cross through the aorta. Later attempts with the right Judkins catheter were also unsuccessful, and the wire could not cross the aorta. In response, a retrograde guidance was used, and the 0.038 inch guidewire and the right Judkins catheter reached the pulmonary artery from the aorta passing through the ductus. Using this catheter as a reference, the multipurpose catheter and the Amplatz 0.035 inch stiff guidewire reached the descending aorta from the pulmonary artery passing through the ductus. By exchanging the catheter on the guidewire, the delivery catheter tip was positioned to the descending aorta. Following this step, the 16-14 ADO device was positioned at the ductus. Only a trace leak throughout the device was observed during the control aortography (Figure 2). Transthoracic echocardiography confirmed the absence of significant leak. After the device was positioned, PAP was $45 / 20$ (34) $\mathrm{mm} \mathrm{Hg}$ and aortic pressure was 125/75 (90) $\mathrm{mm} \mathrm{Hg}$. The procedure was completed with the release of the device. Following its release, the device was observed as being "oversized" and symmetrically shaped in the ductus (Figure 3). On the following day, no residual leak throughout the ductus was observed by TTE. No increase in flow velocity or narrowness was found in the pulmonary artery, its branches, or in the aorta. Other measurements were similar to those observed prior to the procedures. The patient was discharged following recommendations to avoid lifting heavy objects and engaging in competitive sports.

One year after the procedure, the patient was asymptomatic and examination revealed normal heart sounds. Transthoracic echocardiography revealed a decrease in the sizes of the left heart (left ventricle diastolic diameter of $51 \mathrm{~mm}$ ) and ascending aorta (diameter of $35 \mathrm{~mm}$ ). Trace aortic but not mitral insufficiency were observed. The device was in the appropriate position and no residual leakage throughout the ductus was seen with color Doppler. No increase in flow velocity or obstruction was found in the pulmonary artery, its branches, and in the aorta. 


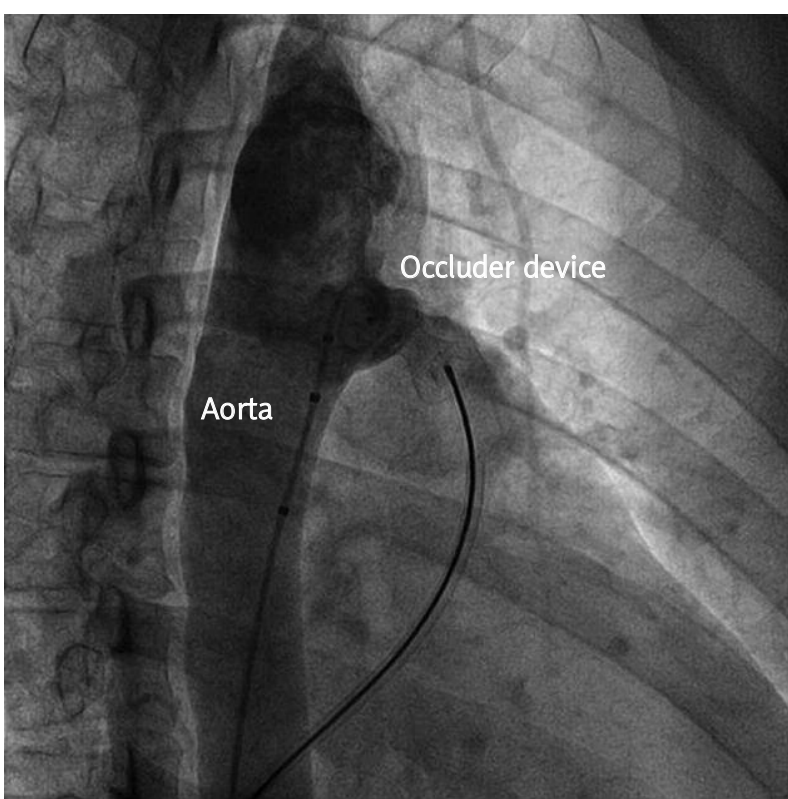

Fig. 2. It is possible to observe in the aortography the occlusion device emplaced within the ducts, as well as the limited leak that takes place only across the device

Ryc. 2. Aortografia przedstawia urządzenie zamykające we wnętrzu przewodu oraz niewielki przeciek, który jest widoczny jedynie wzdłuż urządzenia

\section{Discussion}

Patent ductus arteriosus is the first congenital heart defect to be occluded using surgical and transcatheter methods. The transcatheter closure was successfully used for the first time in 1967 [5]. After decades, by way of coils employed since the 1990s for small ducts (less than $3.5 \mathrm{~mm}$ ) and ADOs for the larger ducts (up to $12-13 \mathrm{~mm}$ ), transcatheter closure of the ducts has become the standard therapy in usual cases [5,6]. Amplatzer duct occluders are devices that are relatively easy to implant and have a high rate of complete occlusion. The use of ADO devices is important, as they are easy to use and allow for rapid closure of middle and large size PDAs (from $3 \mathrm{~mm}$ up to 12-13 mm) [4-6]. The device has an asymmetric design that allows its skirt to be positioned within the aortic ampulla and its body inside the duct during implantation. The body of the device is held tightly within the duct, while the skirt is positioned within the aortic ampulla to prevent embolization of the device to the pulmonary artery. However, there is a risk of device protrusion to the aorta or the left pulmonary artery, especially in small children [7]. Another limitation of the device is the risk of embolization [8] or displacement [2] to the aorta in patients with high PAP, as a result of its asymmetric structure. The use of the Amplatzer duct occluder II (AGA Medical Corp.) was recommended in previous studies to avoid this complication. However, this device can only be used for the closure of PDAs less than $6 \mathrm{~mm}$ in diame-

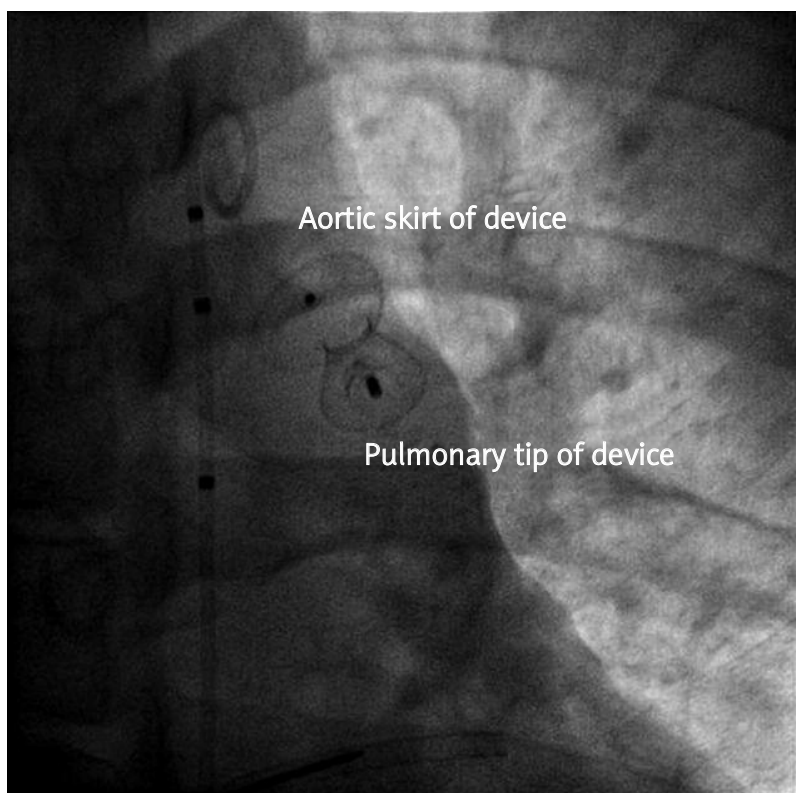

Fig. 3. The "oversized" occluder device can be observed as assuming a symmetrical shape

Ryc. 3. Ponadwymiarowy okluder widoczny po przyjęciu symetrycznego ksztattu

ter [9]. In previous studies, it was reported that using oversized devices would be safe and could reduce the residual leakage, especially among patients with severe pulmonary hypertension [10, 11]. Paç et al. have also recommended the use of larger devices in adult patients to reduce the risk of embolization to the pulmonary artery [11]. Thanopoulos et al. have attempted to use a symmetrically designed Amplatzer muscular ventricular septal defect occluder device (AGA Medical Corp.) to prevent the risk of embolization, and reported successful results [12]. They nevertheless reported in their same publication that they were able to increase the stability of the device by using a larger than recommenced occluder device (by "oversizing," in other words) [12]. However, the waist length of this device is $8 \mathrm{~mm}$, and it may not be suitable for PDA with shorter or longer waist length.

In our case, improved and symmetrical implantation of the device in the ductus was ensured through the use of a device one size larger than the one recommended by the manufacturer. This method can reduce the risk of embolization, especially when used in adult patients with high pulmonary artery pressure and ductus of suitable shape.

\section{References}

1. Huggon IC, Qureshi SA. Is the prevention of infective endarteritis a valid reason for closure of the patent arterial duct? Eur Heart J 1997; 18: 364-366.

2. Dryżek P, Michalak KW, Moszura T, et al. Late coarctation of aorta caused by protrusion of Amplatzer duct occluder - a case report of trans-catheter treatment. Postep Kardiol Inter 2010; 6: 134-137. 
3. Szkutnik M, Kusa J, Banaszak B, et al. Transcatheter closure of persistent ductus arteriosus in adult patients - our experience. Postęp Kardiol Inter 2007; 3: 65-68.

4. The Amplatzer Duct Occluder and delivery system. Instructions for use. AGA Medical Corporation, Golden Valley, MN, USA, 2010.

5. Masura J, Kevin P, Thanopoulos B, et al. Catheter closure of moderate- to large-sized patent ductus arteriosus using the new Amplatzer duct occluder: immediate and short-term results. J Am Coll Cardiol 1998; 31: 878-882.

6. Bilkis AZ, Alwi M, Hasri S, et al. The Amplatzer duct occluder: experience in 209 patients. J Am Coll Cardiol 2001; 37: 258-261.

7. Ing FF, Sommer RJ. The snare-assisted technique for transcatheter coil occlusion of moderate to large patent ductus arteriosus: immediate and intermediate results. J Am Coll Cardiol 1999; 33: $1710-1718$.

8. Faella HJ, Hijazi ZM. Closure of the patent ductus arteriosus with the Amplatzer PDA device: immediate results of the international clinical trial. Catheter Cardiovasc Interv 2000; 51: 50-54.
9. Karapınar H, Küçükdurmaz Z, Sezer S, et al. Procedural success and short- and mid-term results of percutaneous closure of persistent arterial duct with the Amplatzer Duct Occluder II. Turk Kardiyol Dern Ars 2011; 39: 219-223.

10. Yan C, Zhao S, Jiang S, et al. Transcatheter closure of patent ductus arteriosus with severe pulmonary arterial hypertension in adults. Heart 2007; 93: 514-518.

11. Paç FA, Polat TB, Oflaz MB, Ballı S. Closure of patent ductus arteriosus with duct occluder device in adult patients: evaluation of the approaches to facilitate the procedure. Anadolu Kardiyol Derg 2011; 11: 64-70.

12. Thanopoulos BD, Tsaousis GS, Djukic M, et al. Transcatheter closure of high pulmonary artery pressure persistent ductus arteriosus with the Amplatzer muscular ventricular septal defect occluder. Heart 2002; 87: 260-263. 